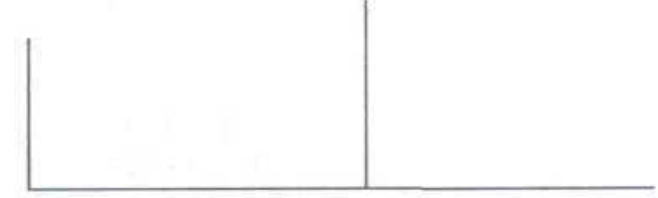

Rev. Latinoam. Psicopat. Fund., III, 2, 174-175

Psiquiatria: propostas, notas, comentários Carol Sonenreich, Giordano Estevão e Luís de Moraes Altenfelder Silva F ${ }^{\circ}$ São Paulo, Lemos 1999

\title{
Psiquiatria: propostas, notas, comentários
}

\author{
Zacaria Borge Ali Ramadam
}

Reconhecer a limitação e o relativismo do conhecimento é incomum nos modernos textos científicos, quase todos caracterizados pela arrogância dos algarismos e o dogmatismo dos gráficos desenhados por complicadas artimanhas estatísticas.

Contudo, essa postura relativista $\mathrm{e}$ - por que não - mais humilde, foi o grande motor das maiores descobertas da Humanidade. Basta conferir a história da ciência e as biografias dos grandes cientistas.

A psiquiatria não foge e essa regra. Os mais importantes periódicos internacionais da área requerem, para sua leitura, mais conhecimentos de matemática e estatística do que de psicopatologia.

Mas psiquiatria, apesar de sua vertente biológica, não é astronomia, é ciência humana, e deve contentar-se, por isso, com suas limitações e o relativismo, já assumidos, há décadas, até pela física teórica e pelos mais eminentes cientistas agraciados com o Prêmio Nobel.

Essa é, sem dúvida, a grande mensagem implícita neste livro, que enfoca temas fundamentais: instrumental da atividade psiquiátrica, alcoolismo e toxicomanias, delírios, depressões, fobias, obsessões e compulsões, transtornos de personalidade, estudos transculturais e tratamento dos distúrbios psíquicos, 


\section{RESENHA DE LIVROS}

sempre de modo crítico e respeitando seus referenciais teóricos.

É um texto inovador e criativo, propondo conceitos mais elaborados e inteligentes para o diagnóstico e a atividade dos psiquiatras.

Há muito tempo não se vê, no cenário nacional, uma obra de tal magnitude e fundamentação científica com tão criteriosa revisão bibliográfica.

Seu principal autor, Carol Sonenreich, é um emérito professor de psiquiatria que formou numerosos discípulos, hoje professores titulares de importantes universidades e outros em funções de relevo em instituições internacionais.

O livro tem, ainda, a seu favor, um estilo agradável, permitindo leitura fluente. É volume indispensável para a biblioteca de especialistas. 